\title{
FRANJO TUĐMAN IN THE SOURCES OF THE REBEL SERBS AT THE BEGINNING OF THE 1990S - AN EXAMPLE OF ANTI-CROATIAN PROPAGANDA
}

\author{
Ante NAZOR*
}

This work presents some legal acts passed and initiatives launched by the Croatian government the aim of which was to protect the rights of the national minorities in Croatia and reach an agreement with the representatives of the Serbs in Croatia so as to avoid armed conflict. The facts presented in this work are important in the context of any given analysis about the issue of whether the Serbs were marginalized with the change of government in Croatia in 1990 and whether their armed rebellion was caused by actions made by the Croatian government and President Tuđman or came as a result of careful planning by proponents of the idea of Greater Serbia. We used a number of documents from the archival material of the Republic of Serbian Krajina to show what had been said and written about President Tuđman in the first half of the 1990s by political and military representatives of those Croatian Serbs that rebelled against the Croatian government and participated in the armed aggression against the Republic of Croatia. We describe how the Serb leadership in the temporarily occupied areas of Croatia accused the Croatian government and Franjo Tuđman of conducting criminal and "national-Fascist" policies against the Serbs and present the facts that completely debunk the accusations. These facts include official documents issued and decisions reached by the Croatian government about protecting the national minorities in Croatia during the mandate of President Tuđman. The work ends with the conclusion that the mentioned accusations were launched for the purpose of creating a greater Serbian state by homogenizing the Serbs.

Keywords: Franjo Tuđman, rebel Serbs, the beginning of the 1990s, anti-Croatian propaganda

* Ante Nazor, PhD, The Croatian Memorial-Documentation Center of the Homeland War, Zagreb, Croatia 


\section{Introduction}

The task of evaluating the role and importance of President Tuđman (1922-1999) within the context of Croatian history is unimaginable without taking into account the fact that under his leadership the Republic of Croatia was created in perilous political (domestic and foreign) and military circumstances during the 1990-1991 period. The Republic of Croatia was forged in a desperate struggle against Serb military aggression. Under Tuđman's direction Croatian diplomacy secured international recognition and the Croatian Army liberated the occupied areas of Croatian territory. Franjo Tuđman served as president while the Croats fought for their very survival in a war imposed on them by Serbian hegemonic aspirations. Countless Croatian civilians lost their lives. One third of the country was occupied and devastated. The Croatian economy suffered and Croatian society was strained to the breaking point not least because the government provided housing and medical and financial aid to hundreds of thousands of refugees and displaced persons from the occupied areas of Croatia and, later on, from Bosnia and Herzegovina as well.

Franjo Tuđman's main objectives were the creation of a sovereign Croatia and its reintegration into Europe. The crucial precondition for realizing those goals, he correctly concluded, was the reconciliation of all political factions in Croatia ("reconciliation of Croatdom"). Tuđman was acutely aware of the pernicious effects of the ideological fault lines dating back to World War II and believed that a universal condemnation of all crimes and abandonment of all follies from the past, like Fascism, Nazism and Bolshevism, coupled with embracing positive societal passions, would go a long way towards effecting the reconciliation of all Croats at the level of society and maybe even result in a political unification of "Croatian Ustashe who wanted a Croatian state" and "Croatian Partisans who fought for Istria". Extremism, no matter its hue, was anathema to Tuđman. He warned that Croatia should not be held hostage to "crazed nutcases on the right" and their "equally psychotic bedlamites on the left". Tuđman also warned against notions of returning Croatia to new regional unions, a resurrected Yugoslavia as it were (the so-called west Balkan), emphasizing that Croatia was an internationally recognized and, having won the Croatian War of Independence, territorially sovereign country.

Tuđman subscribed to the ideal of having as many Croats as possible within the borders of Croatia but, at the same time, he shaped his policies in accordance with the demands of the international community, thus accepting the inter-republic boundaries as state borders. The accepted wisdom was that Bosnia and Herzegovina would not survive because it was plagued by the same problems as Yugoslavia had been. That only exacerbated Tuđman's 
worry about the fate of the Croats in Bosnia and Herzegovina. He understood that the Croats in Bosnia and Herzegovina had to react to the aggressive moves made by the Serbs in Bosnia and Herzegovina and supported all of their efforts at organizing themselves against Serb aggression. That support, it has to be pointed out, was forthcoming only in the context of the boundaries of Bosnia and Herzegovina, and conditioned on Bosnia and Herzegovina's continued survival. Tuđman perceived the presence of Croats in the historical area of Turkish Croatia, that is Banovina Croatia, as a factor of vital importance for the Republic of Croatia. At the same time he accepted all solutions for Bosnia and Herzegovina proposed by the international community. $\mathrm{He}$ himself proposed that Bosnia and Herzegovina be transformed into a confederacy. That solution was in accordance with the recommendations of the international community. It bears pointing out that it was the Croatian-Muslim alliance, based on an agreement reached in Split in July, 1995, that created the necessary preconditions for ending the war in Bosnia and Herzegovina. Equally important were the offensive operations the Croatian Army launched at the end July (Summer 1995) and at the beginning of August 1995 (Storm). Both operations ended in a decisive Croatian victory. As a result, the Serbs were forced to abandon the siege of Bihać, a Muslim enclave in western Bosnia. There is no doubt that, had the Bihać enclave fallen, the Serbs would have committed another genocide against the Muslims, larger in scale than the one they had committed in Srebrenica.

Tuđman wanted to avoid war and prevent loss of life. That consideration was always an important factor in the context of his policies. He made it a point to negotiate for as long as there was even a slightest chance of achieving a peaceful solution. When war was forced on Croatia by the JNA and Serbia, the odds were stacked against Croatia. The UN imposed an embargo on arms and military equipment against the area of the former Yugoslavia. (Resolution 713 , September 25, 1991). That resolution was extremely unfair to Croatia because the JNA was a well-equipped fighting force with large quantities of weapon systems, weapons and equipment, whereas the nascent Croatian armed force had close to nothing (in May, 1990, the JNA confiscated the weapons belonging to the Croatian Territorial Defense, thus effectively disarming Croatia). In such circumstances, Tuđman had to secure Croatia's survival with a small number of men under arms, and an economy, burdened by the war, at breaking point. A significant portion of Croatian territory was under Serb occupation. At the same time, Croatia was undergoing a transition from a Communist style government to democracy. That process was fraught with economic and financial disturbances, compounded by the aftershocks of the break-up of Yugoslavia and monetary volatility accompanying the initiative to privatize the economy. In spite of all of these problems and obstacles, during Tuđman's tenure as president, Croatia became a sovereign democratic country 
featuring all formal mechanisms present in every western democracy. Sometimes these mechanisms did not function effectively and efficiently, but that issue should be assessed within the context of the difficulties the country was forced to contend with during the time-period in question. ${ }^{1}$

\section{Decisions made by the Croatian Parliament and the Croatian government in the 1990s - the basis for coexistence between Croats and Serbs in Croatia}

The political crisis in the Socialist Federative Republic of Yugoslavia (SFRY) at the end of the 1980s heralded a break-up of the country. New political movements, groups and parties sprang up in Socialist Republic Croatia. The Communist Party of Yugoslavia was irretrievably dissolved at the $14^{\text {th }} \mathrm{Ex}-$ traordinary Congress, on January 22, 1990. The political activities initiated for the purpose of implementing greater Serbian policies in Serbia in mid-1980s paved the way for the establishment, towards the end of the decade, of pro-Serbian rule in the autonomous provinces Vojvodina and Kosovo and Socialist Republic Montenegro. The tentacles of these policies spread to Croatia and Bosnia and Herzegovina. Already in February, 1989, the Serbs in Knin held a "warning" rally at which they accused the Croatian leadership of colluding with the Slovenian leadership in "cooperating with Albanian separatists" in the unrests in the autonomous province of Kosovo. The rally was the first in a string of rallies in Croatia at which representatives of those Croatian Serbs who were opposed to Croatia, and politicians from Serbia, issued open threats to the Croats and Franjo Tuđman. The leading Croatian Communists, Ivica Račan and Stipe Šuvar, were damned at those rallies. The speakers announced that the "Serbian lands" extended roughly to the Virovitica - Pakrac - Karlovac - Karlobag line and that they were willing to go to war for that land.

War was inevitable. The outbreak of open warfare was preceded by the armed rebellion of a part of the Serbs in Croatia against the democratically elected Croatian government. It began in Knin in 1990. The leadership of the extreme Croatian Serbs and many Serbian politicians justified the rebellion by claiming that Croatian authorities were mistreating the Serbs. For example, the champions of the rebellion claimed that the Serbs were excluded from

\footnotetext{
Data taken from: James John Sadkovich, Tudman: prva politička biografija [Tudman, the First Political Biography] (Zagreb, 2010); Nikica Barić, "Prvi hrvatski predsjednik dr. Franjo Tuđman o jugoslavenskom predsjedniku Josipu Brozu Titu” [The First Croatian President Dr. Franjo Tuđman on the Yugoslav President Josip Broz Tito], in: Dr. Franjo Tudman u okviru hrvatske historiografije [Dr. Franjo Tudman within the Framework of Croatian Historiography] (Zagreb, 2011), pp. 313-341.
} 
the Croatian Constitution. The claim was a complete fabrication. During and after the war some media outlets propagated the lie that assassinations of Serbs in Croatia, as the most extreme manifestation of the discrimination and repression against the Serbs, had begun in $1990 .^{2}$ Some Serbian politicians in Croatia embraced those lies and used them to justify the Serb rebellion against the Croatian government:

"Liquidations of individuals and large and small groups of Serbs started in the first half of 1991 (according to some sources, even earlier than that). Innocent civilians were taken from their homes, common shelters, their jobs, or were simply snatched off the streets and then murdered. Their bodies ended up in rivers and mass graves."3

At the same time, the official Serbian policies were geared towards convincing the international community that the Republic of Croatia was a successor state to the Independent State of Croatia (NDH - a Quisling polity allied to the Axis powers during WWII) and that the new Croatian government subscribed to the Ustasha ideology from WWII.

It is interesting to compare to what extent were the mentioned accusations, and especially the armed rebellion, caused by decisions made by President Tuđman and the Croatian government in 1990 and 1991. Also, it is important to analyze what part the proponents of the ideology of greater Serbia and purveyors of anti-Croatian propaganda played in influencing and shaping the Serb rebellion in Croatia.

It is a fact that, according to all the existing sources, there is not a shred of evidence suggesting that "liquidations of individuals and large and small groups of Serb started already in the first half of 1991", or before that. There exists no evidence supporting the theory that liquidations of Serbs or murders of persons of Serb nationality motivated by chauvinism took place before the break-out of the high-intensity armed conflict (June 26, 1991, in Banovina). ${ }^{4}$ Moreover, various sources, including the laws passed and the initiatives launched by the Croatian leadership with the aim of establishing a dialogue with representatives of the Serb national minority in Croatia prove that, after the multiparty elections and the constitution of the Croatian parliament on

\footnotetext{
2 Ozren Žunec, Goli život: Socijetalne dimenzije pobune Srba u Hrvatskoj, I [Bare Life: Societal Dimensions of the Serb Rebellion in Croatia, Vol. I] (Zagreb: Demetra, 2007), p. 446 (fn. 820).

3 Milorad Pupovac, "Raspad Jugoslavije i Srbi u Hrvatskoj" [Break-up of Yugoslavia and Serbs in Croatia], Ljetopis Srpskog kulturnog društva "Prosvjeta" II (1997): 260; Žunec, Goli život, p. 587.

4 Žunec, Goli život, pp. 586-588.
} 
May 30, 1990, the Croatian government genuinely tried to work with the representatives of the Croatian Serbs to find a solution to the Serb question in Croatia. For example, Slavko Degoricija, the main negotiator authorized by President Tuđman to conduct negotiations with the rebel Serbs, said that "the Serbs from Knin came to Zagreb eight times" and that he personally had negotiated "with them 52 times" and that "Croatia exhausted all suggested political solutions". ${ }^{5}$ But, the Croat-Serb talks were conducted in an inimical atmosphere, burdened by the all-pervasive campaign of agitation against the democratic processes in Croatia directed by the Serbian media since the end of the $1980 \mathrm{~s},{ }^{6}$ and also by numerous incidents caused by Serb extremists at anti-Croatian rallies in predominately Serb areas in Croatia. Of course, some Croat individuals and groups responded in kind which only increased the tensions. It is a fact that "at the time of the rise of the HDZ party to power in Croatia (1989-1990) the Serb nationalists already had a prepared program for reconstructing Yugoslavia and it was clear that Milošević was bent on realizing it irrespective of the position of Croatia or that of other nations and also, as the constitutional changes in Serbia and the change of government in Montenegro clearly showed, he was already in the process of realizing it." Every reliable source confirms that the Serb rebellion in Croatia and the wars in Croatia and Bosnia and Herzegovina, that is, Serb aggression against the mentioned republics, "were initiated by an attempt to realize the 'all Serbs in one state' project", which then "incited processes of national radicalization in other nations".

Despite constant and numerous provocations, the Croatian police, in such difficult conditions, did its job with utmost professionalism, maximally limiting repression and preventing violence, thus denying the Serb extremists a legitimate pretext for attacks and armed rebellion. The behavior of the JNA put an additional strain on the efforts for finding a peaceful solution to the Serb-Croat question. The JNA, at first covertly and later on openly, supported the Serb extremists and helped them to launch their armed rebellion in Croatia. Shortly thereafter, the JNA openly invaded Croatia. There is no doubt that, in the second half of 1991 definitely but probably even before, the JNA acted in accordance with the political aim of the Serb leadership "effectively representing the regular armed forces of Serbia and Montenegro". ${ }^{8}$ The

\footnotetext{
Slavko Degoricija, Nije bilo uzalud [It Was Not in Vain] (Zagreb, 2009), 295-307.

6 Serbian media outlets, especially those based in Belgrade, had a vital influence on the decision to launch an armed rebellion. One of the leaders of the rebellion, Milan Babić, confirmed this at the Milošević trial in The Hague. See: Žunec, Goli život, p. 569 (fn. 1107).

Žunec, Goli život, pp. 109-110.

8 Žunec, Goli život, p. 188 (fn. 307).
} 
then federal secretary of people's defense of SFRY Veljko Kadijević confirms this in his book. ${ }^{9}$

The adversarial stance of the JNA towards the democratic processes and change of government in Croatia was manifested in the disarming of the Croatian Territorial Defense Force (republic branch of the armed forces of SFRY), which the JNA conducted in mid-May, 1990, immediately after the elections and prior to the constituting of the new, multiparty Croatian Parliament. ${ }^{10}$ In August, 1990, the JNA prevented the Croatian police from reestablishing law and order in the areas under rebellion. ${ }^{11}$ One year after that, on September 21, 1991, the then Federal Secretary of People's Defense of SFRY Veljko Kadijević publicly stated that the JNA would launch decisive actions in order to "prevent a civil war". With that statement Kadijević confirmed that the leadership of the JNA did not recognize the Croatian government as legitimate. The statement was also tantamount to a declaration of war on Croatia. ${ }^{12}$ Ignoring the peace talks, that is, attempts of the Croatian government and the international community to stop Serb aggression by peaceful means, the JNA and Serb-Montenegrin forces launched, at the end of September and beginning of October, an all-out offensive on all fronts in Croatia. The objective of the offensive was to decisively defeat the Croatian forces in 20 days. ${ }^{13}$ In such difficult conditions the Croatian government succeeded in securing a high level of autonomy for the Serb minority in Croatia. It also successfully protected the ethnic rights of the Serb minority. The Croatian government made these moves not only because the international community insisted on them, but

\footnotetext{
$9 \quad$ Veljko Kadijević, Moje viđenje raspada [My View on the Break-up] (Belgrade, 1993), 93; See more: Davor Marijan, Slom Titove armije - JNA i raspad Jugoslavije 1987-1992 [The Defeat of Tito's Army and the Break-up of Yugoslavia] (Zagreb, 2008).

10 Republika Hrvatska i Domovinski rat 1990-1995, Dokumenti, knjiga 1, Oružana pobuna Srba u Hrvatskoj i agresija Oružanih snaga SFRJ i srpskih paravojnih postrojbi na Republiku Hrvatsku, 1990-1991 [The Republic of Croatia and the Croatian War of Independence 19901995, Documents, Vol. I, Armed Rebellion of the Serbs in Croatia and Aggression of SFRY Forces and Serb Paramilitary Formations against the Republic of Croatia 1990-1991], Mate Rupić, ed. (Zagreb: Hrvatski memorijalno-dokumentacijski centar Domovinskog rata, 2007), pp. 13, 19 and 24 .

11 About the reactions of the JNA after JNA jets intercepted Croatian police helicopters tasked with reestablishing law and order in Knin on August 17, 1990, see: Hrvoje Kačić, $U$ službi domovine [In the Service of the Homeland] (Zagreb, 2006), pp. 72-74.

12 Anton Tus, "Rat u Sloveniji i Hrvatskoj do Sarajevskog primirja" [The War in Slovenia and Croatia until the Sarajevo Ceasefire"], in: Rat u Hrvatskoj i Bosni i Hercegovini 1991-1995 [The War in Croatia and Bosnia and Herzegovina 1991-1995] (Zagreb-Sarajevo: Naklada Jesenski i Turk - Dani, 1999), p. 74.

$13 \quad$ I Ibid., p. 78.
} 
also because it genuinely believed that protecting the human rights of every Croatian citizen was essential for efficient and viable functioning of the state.

As a reaction to unconstitutional decisions of the leadership of the rebel Serbs and terrorism of Serb extremists in Croatia, and, from August, 1990 onwards, to the armed rebellion against Croatia, and, from summer 1991 onwards, to open aggression led by Serbia with the help of the armed forces of the SFRY (the JNA, Territorial Defense Forces of Serbia, Montenegro and part of Bosnia and Herzegovina) troops belonging to the Serbian Ministry of Internal Affairs and Serb paramilitary forces and the rebel Serb formations, the Croatian Parliament passed various resolutions and decisions with the aim of protecting the constitutional and legal order and territorial integrity of the Republic of Croatia. In addition, the Croatian leadership reacted to the actions and documents which confirmed the responsibility of the Republic of Serbia for the events in Croatia. At the same time the Croatian government, despite the fact that the attacks of Serb forces were causing human suffering on a massive scale and immense material damage, protected the rights of all minorities, and especially the Serb minority, in Croatia. The rights of the Serb minority were especially addressed, not only because the Serb minority was the most numerous minority in Croatia but also because other minorities did not express discontent or questioned the legality of the democratically elected Croatian government.

The content of the new Croatian Constitution of December 22, 1990 testifies to the fact that the Croatian government tried to solve the Serb question in Croatia by peaceful means and also to the fact that the level of Serb autonomy and protection of the rights of the Serb minority secured by the Croatian government was high. By this, the most important legal act, all civil rights were guaranteed to all citizens (freedom of thought, expression and association and equality of all persons before the law regardless of gender, religion, nation, political beliefs etc.), the principle of equality of all nations and minorities and their right to express their national and ethnic affiliation, to use their own language and script and enjoy cultural autonomy was guaranteed:

"The Republic of Croatia is hereby established as the nation state of the Croatian nation and the state of the members of its national minorities: Serbs, Muslims, Slovenians, Czechs, Slovaks, Italians, Hungarians, Jews and others who are its citizens and who are guaranteed equality with citizens of Croatian nationality and the exercise of their national rights in accordance with the democratic norms of the United Nations and the countries of the free world. (from Chapter I, Historical Foundations)

Article 1: The Republic of Croatia is a unitary and indivisible democratic and social state. 
Article 2: The sovereignty of the Republic of Croatia is inalienable, indivisible and non-transferable.

Article 3: Freedom, equal rights, national and gender equality, peace-making, social justice, respect for human rights, inviolability of ownership, conservation of nature and the environment, the rule of law and a democratic multiparty system are the highest values of the constitutional order of the Republic of Croatia and the basis for interpreting the Constitution; (...)

Article 14: All persons in the Republic of Croatia shall enjoy rights and freedoms, regardless of race, colour, gender, language, religion, political or other opinion, national or social origin, property, birth, education, social status or other status. All persons shall be equal before the law. (...)

Article 15: Equal rights for the members of all national minorities in the Republic of Croatia shall be guaranteed. (...)

Article 140: The Republic of Croatia remains part of the Socialist Federal Republic of Yugoslavia until a new agreement is reached by the Yugoslav republics, or until the Croatian Parliament decides otherwise."14

The representatives of the rebel Serbs in Croatia interpreted the new Croatian Constitution as just another piece of evidence proving that the new Croatian government abrogated the Serbs' position as a constituent nation, turned them into a national minority and reduced them to "second class citizens". The representatives of the rebel Serbs in Croatia further claimed that the Croatian government had stripped the Serbs of their previously established sovereignty and used the claim as justification for worsening their relations with the Croatian Parliament. ${ }^{15}$ These claims were in stark contradiction with both the letter and the spirit of the Constitution of Socialist Republic Croatia of 1974. It is stated, in the text of that Constitution, that "Socialist Republic Croatia was a national state of the Croatian people, a state of the Serb people in Croatia and a state of other peoples and ethnicities which live in Croatia."16

\footnotetext{
14 "The Constitution of the Republic of Croatia", Narodne novine, issue 56, December 22, 1990.

15 "Mišljenje Pravne komisije Srpskog nacionalnog vijeća u svezi nacrta Ustava Republike Hrvatske, 24. rujna 1990., "[The Opinion of the Legal Council of the Serbian National Committee about the Draft Constitution of the Republic of Croatia, September 24, 1990] Republika Hrvatska i Domovinski rat 1990-1995, dokumenti, knjiga 2, Dokumenti institucija pobunjenih Srba u Republici Hrvatskoj, 1990-1991, Mate Rupić, ed. (Zagreb: Hrvatski memorijalno-dokumentacijski centar Domovinskog rata, 2007), 72.

16 The SFRY Constitution - SR Croatia Constitution, Jakov Blažević (Zagreb, 1974), 245. There is no mention of the constitutionality of Serbs in the Constitution of People's Republic
} 
The wording of the text is unambiguous and does not allow interpretations according to which it could be concluded that the Serbs, at that time, enjoyed the status of a constituent nation in Croatia. They did enjoy, however, a "special status in relation to other nations and ethnicities". ${ }^{17}$ Irrespective of the subtleties in the text of the Constitution or lack thereof, the chronology of violence unleashed by Serb extremists a few months before the passing of the new Croatian Constitution clearly shows that the mentioned changes in the wording of the Constitution had nothing to do with the steady increase of tensions in international relations in Croatia and were not the cause of the war in Croatia. ${ }^{18}$

The representatives of the disaffected Serbs in Croatia had other objections to the content of the Croatian Constitution. These objections were presented by the Legal Council of the Serbian National Committee on September 24, 1990, in "the opinions and recommendations related to the drafting and content of the Constitution of the Republic of Croatia". Amongst other recommendations was a proposal that the following provision be included in the Croatian Constitution: "In the Republic of Croatia there are Autonomous provinces as forms of territorial autonomy or as forms of cultural autonomy". ${ }^{19}$

It has to be pointed out that before the passing of the new Croatian Constitution the Croatian Parliament had reached decisions that guaranteed equality to all citizens of the Republic of Croatia. On August 24, at an extraor-

of Croatia from 1947. The equality of Serbs and Croats in Croatia, however, is specified in the text. The Croatian Constitution of 1990 guarantees equality to all Croatian citizens. In the basic principles of the Constitution of People's Republic of Croatia, passed on January 18, 1947, it is stated: that "People's Republic of Croatia executes its authority in a sovereign manner, transferring to the FNRJ [Federativna Narodna Republika Jugoslavija - Federal People's Republic of Yugoslavia] only those rights that are determined by the FNRJ Constitution" (Chapter III, Article 10), that "the Serbs in PR Croatia are equal with the Croats" (Article 11), that "every act, committed against the sovereignty, equality and national freedom of the Croatian people, against the equality of the Serbs and Croats in PR Croatia, against PR Croatia and against other nations and nationalities of the FNRJ is unconstitutional" (Article 12), that "the boundaries of PR Croatia cannot be altered without the PR Croatia Assembly's consent" (Article 13), that "national minorities in PR Croatia enjoy the right to and protection of their cultural development and freedom to use their own language" (Article 14). See: Zbirka zakona, uredaba $i$ naredaba Narodne Republike Hrvatske, broj 5, Ustav Narodne Republike Hrvatske [Collection of Laws, Acts and Orders of People's Republic of Croatia, No. 5, Constitution of the People's Republic of Croatia] (Zagreb, 1947), pp. 5, 6, 8 and 9.

17 Zdenko Radelić, Davor Marijan, Nikica Barić, Albert Bing and Dražen Živić, Stvaranje hrvatske države i Domovinski rat [The Creation of the Croatian State and the Homeland War] (Zagreb: Školska knjiga, Hrvatski institut za povijest, 2006), p. 94.

18 Žunec, Goli život, p. 104.

19 Republika Hrvatska i Domovinski rat 1990-1995, dokumenti, knjiga 2, p. 74. 
dinary session of the Croatian Parliament, the Resolution on Protecting the Democratic Order and National Rights in Croatia was passed. The intention to protect "the constitutional order and laws of the Republic of Croatia" is clearly stated in the resolution. Also, the text of the resolution unambiguously displays the unwavering intention of the Croatian government to "guarantee all human, political and national rights to all people living in Croatia". To realize these intentions the Croatian Parliament accepted the obligation of "securing further constitutional and legal institutionalization of the protection of human, political and national rights in the Republic of Croatia". The Croatian Parliament called on the "European Parliament and other qualified public and private organizations committed to investigating and monitoring the situations regarding respect for human, political, national and ethnic rights in the world to send their observers or representatives to Croatia to see for themselves the situation on the ground in relation to honoring said rights and especially in relation to the Croat and Serb populations in the areas affected by the rebellion." 20

On April 17, 1991, the Croatian Parliament passed the Declaration on Condemning the People's Assembly of Republic of Serbia for Interfering with Internal Affairs of the Republic of Croatia, rejecting the claims contained in the Declaration of the People's Assembly of Republic of Serbia of April 2, 1991, as "arbitrary, untrue and militant". The Croatian Parliament specifically emphasized that "in the Titova Korenica municipality, that is, Plitvice, Pakrac and other locales in the Republic of Croatia in which the organs of state authority have efficiently re-established law and order, force was not used against the 'interests of the Serbian people', but was used against individual terrorists and groups which had been disrupting the legal order of the Republic of Croatia and endangering the lives of Croatian citizens". The Croatian Parliament pointed out that "terrorist activities in certain areas of Croatia, including disrupting the transport of goods and people, setting explosives on railroad tracks, armed robberies, pillaging and murder, have reached such proportions that the Croats, and all other citizens of the Republic of Croatia, could no longer tolerate the situation" and that "the creators, instigators and perpetrators of those violent terrorist acts are the followers of the idea of Greater Ser-

\footnotetext{
20 "Izvješće u povodu inicijative Vlade Republike Hrvatske, klasa: 004-01/02-02/12, ur. broj: 5030109-02-2 od 10. listopada 2002. godine" [Report regarding the initiative of the Croatian government, class: 004-01/02-02/12, number: 5030109-02-2 of October 10, 2002] Constitutional Court (President of the Court, dr. sc. Smiljko Sokol), No.: U-X-2271/2002, Zagreb, November 12, 2002, 31-32 (hereinafter Constitutional Court); the same report in: "Dokumentacija Ustavnog suda Republike Hrvatske o Domovinskom ratu" [Documentation of the Constitutional Court of the republic of Croatia on the Homeland War], Hrvatsko slovo, No. 400, December 20, 2002, Appendix.
} 
bia and practitioners of hegemonist-unitarist, imperialistic policies and have their HQ in Belgrade, which the Declaration obviously confirms". It was also stated in the text that the Declaration of the People's Assembly of Republic of Serbia tried to accord legality and legitimacy to an imaginary, unconstitutional and legally non-existent polity and its organs and that the polity in question represents "a most callous and organized attack on the sovereignty and territorial integrity of the Republic of Croatia and that the Serbian Democratic Party is, more so than any other factor, responsible for that state of affairs." On the other hand, the Croatian Parliament acknowledged that "a majority of the Serb population in Croatia is loyal to the Republic of Croatia as their homeland and respects its democratically elected state organs". ${ }^{21}$

At the same session, on April 17, 1991, the Croatian Parliament issued the Conclusions on the Political Situation in Croatia. That document contained, amongst other things, a request to the Croatian government and its organs to "within their respective purviews undertake, in a timely and energetic manner, all necessary actions for the protection of the legal order in the entire territory of the Republic of Croatia"' and to "efficiently protect the rights of parts of peoples and national minorities, equally parts of the Croatian people living in other countries and parts of peoples and national minorities living in Croatia, with the proviso that the members of national minorities and peoples in question respect the legal order of the country of their residence". Also, the Croatian Parliament requested the JNA to "withdraw its troops to the barracks so that law and order could be kept in the Republic of Croatia by the country's forces of law and order."22

Due to the aggressive and exclusive Serb policies and also due to the refusal of the rebel Serb leadership to cooperate with Croatian authorities, Croatia (at the same time as Slovenia) made its first moves towards independence. On June 25, 1991, the Croatian Parliament reached, on the basis of the results of the May 191995 referendum, the Constitutional Decision on Sovereignty and Independence of the Republic of Croatia and the Declaration on Establishing a Sovereign

\footnotetext{
${ }^{21}$ Constitutional Court, 34-35; The mentioned Declaration of the People's Assembly of the Republic of Serbia confirmed the direct interference of the leadership of the Republic of Serbia in and responsibility for the rebellion in Croatia. U Terrorist units entered Croatia from Serbia, and some Serbian officials, even some members of the government of the republic of Serbia and the Assembly of the Republic of Serbia, propagated violence and incited people to rebellion at rallies in Croatia. On May 2, 1991, Serb extremists killed 12 Croatian police officers in Borovo Selo near Vukovar. The atrocity happened some 10 days after Milan Paroški, a member of the Assembly of the Republic of Serbia, said, in his speech given at a Serb rally in Jagodnjak in Baranja (Croatia) on April 21, 1991, that "this is Serb territory" and that anyone who says otherwise "should be killed like a dog".
}

22 Constitutional Court, 35-36. 
and Independent Republic of Croatia and issued the Charter of the Rights of Serbs and other Nationalities in the Republic of Croatia, confirming the obvious intention of the Croatian authorities to cooperate with the Croatian Serbs and to secure the necessary conditions for a peaceful coexistence:

"I) A just solution of issues concerning Serbs and other nationalities in the Republic of Croatia is one of the essential factors of democracy, stability, peace and economic prosperity, and of cooperation with other democratic countries.

II) The protection and full realization of the rights of all nationalities in the Republic of Croatia, and the protection of rights of individuals are constituent parts of the international protection of human and civil rights and the protection of nationalities, and as such belong to the sphere of international cooperation.

III) The rights of nationalities and international cooperation do not allow any activities contrary to the principles of international law, and especially of the sovereignty, territorial integrity and political independence of the Republic of Croatia.

IV) All nationalities in Croatia shall have the right to be protected against all activities that may endanger their existence, they shall have the right to be respected, the right to self-preservation and to cultural autonomy.

V) Serbs and other nationalities in Croatia shall have the right to participate proportionally in the bodies of local self-government and in adequate bodies of government authorities. They shall have the right to secure their economic and social development for the purposes of preserving their identity and being protected from any attempt at being assimilated. An organization which is in conformity with the objectives defined in its by-laws, concerned with the protection and development of a particular nationality and thereby acts as its representative, shall have the right to represent it as a whole and its individual members, both within the state and internationally. (...) In order to protect their rights, individual nationalities and their members shall have the right to apply to international institutions called upon to protect human and national rights. ${ }^{23}$

The decisions made by the Croatian Parliament on June 25, 1991, initiated the process of Croatia's dissociation from Yugoslavia. The same process entailed preparing the necessary conditions for international recognition. However, at the EC's request Croatia and Slovenia signed the Briuni Declaration in July, 1991, and postponed declaring independence for three months. The EC hoped that the postponement would be conducive to finding a peaceful solu-

23 Constitutional Court, 37. 
tion of the Yugoslav crisis. ${ }^{24}$ In accordance to this development, the President of the Croatian Parliament Doctor Žarko Domljan launched, on July 24, 1991, an initiative with the aim to solve the Serb question in Croatia by peaceful means and dissuade the rebel Serbs from participating in the ongoing aggression against Croatia. Žarko Domljan invited the leaders of all political parties that were at that time active in Croatia to a meeting. He wanted to initiate a democratic dialogue, an honest exchange of opinions so as to achieve a political consensus regarding the rights of nationalities which would stem from constitutional solutions and the Charter of the Rights of Serbs and other Nationalities in the Republic of Croatia. ${ }^{25}$

The meeting was held on July 30, 1991, in the parliament building, in the government's conference hall (Stjepan Radić Square 6). The result of the meeting was the appointment of the Parliamentary Commission for Protection and Promotion of Equality of Nations and Ethnicities. It is worthy of note that Slavko Degoricija was present at the meeting at Tuđman's insistence. Tuđman completely trusted Degoricija's judgment when it came to issues regarding cooperation with the Serbs in Croatia. ${ }^{26}$ The Parliamentary Commission set up a work group and that work group drafted a document entitled The Starting Points for Achieving Cultural Autonomy, Local Self-Government and Administration and Proportional Participation of Persons of Serb Nationalities in the State Organs of the Republic of Croatia. The basic determinants of the document emphasized the value of national and ethnic communities, anti-assimilationist policies of the state, the imperative that the state secure for the ethnic groups everything apart demands that could bring into question the democratic order and the sovereignty of the Republic of Croatia and the imperative that the political relations between the Republic of Croatia and the Serb people in Croatia be regulated by Constitutional law which would ensure cultural autonomy, local self-government (territorial autonomy) and proportional representation (political autonomy). But, the leadership of the Serbs from Knin did not accept the offer made by the Croatian government about political and cultural autonomy in the republic of Croatia. ${ }^{27}$

Despite the fact that Slovenia and Croatia signed the Brijuni declaration and agreed to introduce a three-month moratorium on their June 25 decision to declare independence, the Serb rebels in Croatia intensified their terrorist

\footnotetext{
24 About the Brijuni Declaration see: Hrvoje Kačić, U službi domovine, p. 140 (fn. 17).

25 The Croatian Parliament, Invitation of the President of the Parliament Doctor Žarko Domljan to the leaders of all political parties that were active in Croatia in 1991, number: 6333-91-47, Zagreb, July 24 1991; Slavko Degoricija, Nije bilo uzalud (Zagreb: 2009), 26.

26 Degoricija, Nije bilo uzalud, 26.

27 Ibid., 27-33.
} 
activities during the summer. A number of terrorists came from Serbia. These acts of terrorism escalated into a merciless and open aggression against the Republic of Croatia. The JNA played the main role in the onslaught. The Croatian Parliament reacted and issued, on August 3, a document entitled Conclusions. The document, amongst other things, called on "all international humanitarian organizations engaged in supervising and monitoring the observance of human rights to send their representatives to Croatia to ascertain the situation on the ground in relation to all issues regarding human, civil, national and minority rights of Serbs and all other minorities living in Croatia". The Croatian Parliament also called on "JNA members, Serbs in Croatia and members of all other Yugoslav nationalities to refuse to participate in hostile acts against Croatia, unite in their opposition to the Communist imperialism of the Republic of Serbia and to the Communist-Stalinist structures in the JNA and federal organs". The mentioned Conclusions initiated the forming of the Commission for Crimes against Civilians and Humanity in the Republic of Croatia during the Aggression. ${ }^{28}$

On October 8, 1991, at the height of the JNA's all-out onslaught on Croatia, the Croatian Parliament confirmed the Republic of Croatia's independence and the definitive termination of all state-legal ties with the SFRY. The members of the Croatian Parliament also concluded that the JNA, "as an aggressor and an army of occupation" had to withdraw promptly from the territory of the Republic of Croatia and called on Bosnia and Herzegovina and Montenegro to refuse the usage of their territories for military operations against Croatia. ${ }^{29}$ The Republic of Croatia based its right to independence, amongst other things, on a number of provisions of the then valid Yugoslav Constitution of 1974, which affirmed the statehood and sovereignty of the republics and on the content of text of the Republic Constitution of 1974, by which "the Croatian people has established its Socialist republic of Croatia on the basis of the right to self-determination, including the right to secession and union with other peoples according to its freely expressed preference and for the purpose of protecting its national independence and freedom." ${ }^{30}$

It bears mentioning that the October 81991 session of the Croatian Parliament was held in dramatic circumstances. The danger of an air raid on the parliament building was clear and present. That, however, did not dissuade the members of parliament to discuss the issue of the rights and equality of the national minorities in Croatia. The Prime Minister, Franjo Gregorić, at that session, addressed the issue:

28 Constitutional Court, pp. 37-39.

Narodne novine, issue 53, October 8, 1991; Constitutional Court, p. 39.

30 The SFRY Constitution - SR Croatia Constitution, p. 224. 
"The Conclusions of the Parliament of August 31991 and the unanimous acceptance of the Government of Democratic Unity proved that the Croatian nation and Croatian citizens are united in their determination to defend, as I pointed out at the inauguration of the government of the Republic of Croatia, the sovereignty of the Republic of Croatia, freedom, national equality, peace, social justice, respect for human rights, inalienability of the right to private property, immutability of the existing republic boundaries, the rule of law and democratic multi-party system. The mentioned values form the foundation of the constitutional order of the Republic of Croatia, but also represent the basic principles for the functioning of the government, as stated in the Multiparty Agreement (....."31

The Sarajevo Ceasefire was signed on January 2, 1992. By that time the JNA and Montenegrin units had managed to occupy almost one third of Croatian territory. In such circumstances, grounded in the basic determinants of the treatment of national minorities and conditions set by the international community for recognizing the sovereignty of the Republic of Croatia, the Croatian Parliament passed, on December 4, 1991, the Constitutional Law on Human Rights and Freedoms and Rights of Ethnic and National Communities or Minorities in the Republic of Croatia. ${ }^{32}$ That law secured all human rights and freedoms, cultural autonomy and other rights related to ethnic and national minorities or communities, to the Serbian minority in Croatia, including the official usage of language and script (in the municipalities where members of an ethnic and national community or minority compose the majority of a total number of inhabitants) and proportional representation in representative, administrative and judicial organs of the Republic of Croatia. The law also gave the 11 municipalities where the Serbs formed an absolute majority (Dvor, Glina, Hrvatska Kostajnica, Vojnić, Vrginmost, Benkovac, Donji Lapac, Gračac, Knin, Obrovac and Titova Korenica) a special self-governing status. Also, all municipalities enjoying the special self-governing status were allowed to join into communities.

The Arbitration Commission of the Conference on Yugoslavia accepted the law but asked the Croatian government to amend and supplement it. Immediately prior to being accepted into the UN (May 22, 1992), the Croatian Parliament, by its decision of May 81992 about amending and supplementing the Constitutional Law on Human Rights and Freedoms and Rights of Ethnic and National Communities or Minorities in the Republic of Croatia, enabled

\footnotetext{
31 "Istekao moratorij, zbogom, Jugoslavijo" [Moratorium has expired - goodbye Yugoslavia]excerpt from a speech given by Prime minister Franjo Gregurić at the October 81991 session of the Parliament, Večernji list, Wednesday, October 10, 1991.
}

32 Narodne novine, issue 65, 1991. 
the Serbs in Croatia, as the most numerous national minority in Croatia, to form two autonomous districts - Knin and Glina - with a special status. ${ }^{33}$ In accordance with the 1991 law, these districts would unite the joined municipalities with absolute Serb majorities and where the Serbs enjoyed a higher degree of self-government. The mentioned law "satisfied the demands of International law regarding the protection of minorities". The envisaged districts would consist of the 11 municipalities, as according to the law of December 4, 1991, with the difference that: the municipalities of Knin, Obrovac, Benkovac, Gračac, Titova Korenica and Donji Lapac would form the autonomous district of Knin and the municipalities of Glina, Vrginmost, Hrvatska Kostajnica, Dvor na Uni and Vojnić would form the autonomous district of Glina (article 22). ${ }^{34}$ But, the leadership of the rebel Serbs did not care about the laws passed by the Croatian government. The rebel Serbs wanted to join the areas in question to Serbia and so their leaders refused the Croatian government's proposal.

On June 3, 1992, based on Article 41 of the Constitutional Law on Human Rights and Freedoms and Rights of Ethnic and National Communities or Minorities in the Republic of Croatia, the Legislative-legal Commission of the Croatian Parliament, at the June 31992 session, determined the consolidated text of the Constitutional Law on Human Rights and Freedoms and Rights of Ethnic and National Communities or Minorities in the Republic of Croatia. ${ }^{35}$ With that, the Constitutional law of December 4, 1991, which also adhered to high standards regarding the protection of human rights and freedoms, and rights of the ethnic and national communities or minorities, was made better in accordance with the interests of the Serbian and other ethnic communities in the Republic of Croatia.

The Constitutional law of May 8, 1992 was made by taking into consideration the recommendations made by the International Conference on the Former Yugoslavia. The recommendations were contained in a note attached to the letter which the president of the European Council sent to the president of the Republic of Croatia on February 22, 1992 (Articles 22, 60 and 63 were added and Article 62 was removed). The changes strengthened the guarantees to the Serbs regarding their autonomy in the districts of Glina and Knin and also allowed them to form a temporary court of human rights. The Arbi-

\footnotetext{
33 Narodne novine, issue 27, 1992.

34 Ibidem.

35 Narodne novine, issue 34, 1992; The consolidated text of the Constitutional Law on Human Rights and Freedoms and Rights of Ethnic and National Communities or Minorities in the Republic of Croatia contains the Constitutional Law on Human Rights and Freedoms and Rights of Ethnic and National Communities or Minorities in the Republic of Croatia (Narodne novine 65, 1991) and its amendments as published in Narodne novine, issue 27, 1992. The dates when these amendments were put into effect are indicated.
} 
tration Commission observed that this supplemented Constitutional law fell short of the mark in relation to certain obligations Croatia had taken on by accepting the provisions of the draft convention of November 4, 1991, but still concluded that the law "meets the demands of International law as regards the protection of minorities" and that "Article 6(e) was especially in accordance with the imperative norm of International law according to which every human being has the right to choose his or her ethnic, religious or linguistic affiliation within the framework of a national collectivity". ${ }^{36}$

The Constitutional Law on Human Rights and Freedoms and Rights of Ethnic and National Communities or Minorities in the Republic of Croatia of December, 1991, and the Constitutional Law on Human Rights and Freedoms and Rights of Ethnic and National Communities or Minorities in the Republic of Croatia of 1992 were passed on the basis of Articles 3,14 and 15 of the Croatian Constitution so as to:

"- to protect and ensure the exercise of the rights of man and ethnic rights on the highest level achieved in democratic environments of the contemporary international community,

- to enable the citizens of less numerous ethnic and national communities or minorities, or citizens of the same religious, racial or language affiliation, to freely develop their particular qualities within the framework of the majority community of citizens or majority communities without abuse by either the majority or a minority,

- in accordance with the wish for the Republic of Croatia to be a modern, open, democratic member of the family of European and world states, in which its citizens, in the course of enjoying their civil, political and other rights, would not be divided according to ethnicity, language, religion, inherited or naturally caused human marks,

- bearing in mind the efforts of the international community, especially of the European Union and the Peace Conference on Yugoslavia in The Hague for the solution of open issues created by the disintegration of Yugoslavia and creation of new states in its area.

Therefore, The Constitutional Law on Human Rights and Freedoms and Rights of Ethnic and National Communities or Minorities in the Republic of Croatia prescribes and guarantees: the protection of "the equality of members of ethnic minorities" and of their "ethnic, cultural and linguistic development" (Chapter II Article 3-4); cultural autonomy and other rights of ethnic

\footnotetext{
36 Vladimir Đuro Degan, Hrvatska država u međunarodnoj Zajednici - Razvitak njezine medunarodno pravne osobnosti tijekom povijesti [Croatia in the International Community the development of its international-legal character throughout history] (Zagreb: Nakladni zavod Globus, 2002), pp. 356-357.
} 
and national communities or minorities; (Chapter III Article 5-13); education of members of ethnic and national communities or minorities in the Republic of Croatia shall be conducted in kindergartens and schools in their language and script, according to special programs into which their history, culture and science has been appropriately included, provided they wish so and also that members of ethnic and national communities or minorities may establish private kindergartens, schools and other teaching establishments (Article 14-17); the right to representation in the bodies of local self-government proportionally to their share in the total population of a certain local self-government unit (Chapter IV Article 18-20); special self-governing (autonomous) statute to an ethnic and national community or minority, if members of the group in question form an absolute majority, according to the 1981 census results, in the area in question (Chapter V Article 21-22). It was emphasized in the text of the law that the structure of the districts with a special statute must not be in contradiction to the constitutional order of the Republic of Croatia as a unitary and indivisible state.

The President of the Republic of Croatia Franjo Tuđman, followed up the passing of the Constitutional law by issuing the Decree of September 25, 1992, by which he declared the Act on the State Attorney's Office. The act was based on Article 89 of the Croatian Constitution. That same day the House of Representatives of the Croatian Parliament passed the act. The act stipulated that the State Attorney was responsible for scrutinizing individual cases of violation of rights of citizens committed by organs of state administration, by organs with public authority prerogatives or by employees of said organs. ${ }^{37}$

The leadership of the rebel Serbs ignored all of the above and continued implementing the policies geared towards joining the occupied areas of the Republic of Croatia with Serbia.

\section{Tuđman in the sources of the rebel Serbs}

President Tuđman offered cooperation to the Croatian Serbs, but he refused to relinquish any part of Croatian territory to the rebel Serbs. He promised to respect the civil and national rights of the Croatian citizens of Serbian ethnicity and he expected that the Serbian authorities would respect the rights of the Croats living in Serbia. In November 1991, the fate of Croatia hung in the balance. Vukovar was besieged and about to fall. The Serb forces were engaging in an orgy of destruction, war crimes and crimes against humanity against Croatian civilians on Croatian soil. It would have been easy for Tuđman, the

$37 \quad$ Narodne novine, issue 60, 1992. 
Croatian government and Croatian people to succumb to rage and thirst for vengeance and start brutalizing ethnic Serbs. President Tuđman would have none of it. He demanded of the representatives of the Croatian authorities to make sure that the Croatian Serbs' civil and national rights be respected (Transcript from the November 14, 1991 meeting in the Office of the President). Despite this fact, at the beginning of the decade the Serb media, including JNA publications, were creating a flurry of fatuous, vituperative, absurd, opprobrious, and scurrilous stories, excoriating Croatia and President Tuđman.

The attacks on the new government in Croatia and President Tuđman in the Serbian press followed, for the most part, the same pattern: an event would be invented or misinterpreted and then blown out of all proportion to create an illusion of crisis suitable for presenting generalized arguments and declarative negative conclusions about the Croatian president and/or the Croatian government. This media campaign had all the hallmarks of Goebbels-style propaganda and it was utilized by the detractors and opponents of the democratic changes in Croatia. Most of these people subscribed either to the grater Serbian ideology or Communist ideology. The propaganda/information war was launched immediately after the HDZ party won the elections in May, 1990. It has to be pointed out that the Communist ideology and the greater Serbian ideology were opposing, and ideologically irreconcilable political creeds. The alliance between the two was only made possible because both options shared a common interest in preserving Serb dominated Yugoslavia as a centralized state.

The leadership of the JNA and that of the Serb Communists had very similar opinions on the political changes in the western Yugoslav republics; Croatia and Slovenia. They also shared perceptions regarding the issues of societal development in Yugoslavia. Borisav Jović, one of the leading Serbian officials, recognized the phenomenon as early as the summer of $1989 .{ }^{38}$ If Yugoslavia were preserved, even in a rump form (without Slovenia and part of Croatia) the Communist-Yugoslav oriented JNA officers would keep their privileges. At the same time, the main objective of the radical Serb nationalists (all Serbs in one state with the western boundary deep in Croatian territory, running along the Virovitica - Pakrac - Karlovac - Ogulin - parts of Gorski Kotar - Karlobag line) would be achieved. And so, under the guise of striving to preserve Yugoslavia, the JNA, a well-equipped force, became the main armed force used for realizing the greater Serbia project.

With the aim to vilify the Croatian leadership and prevent democratic changes in Croatia, the architects of the propaganda war against Croatia staged, on May 18, 1990, in Benkovac, an attack on Miroslav Mlinar, the presi-

Žunec, Goli život, p. 204 (fn. 339). 
dent of the local "board" of the Serbian Democratic Party (SDS). The Croatian public condemned the attack. But, the Serb media and some Serbian politicians decided not to wait for the results of the police investigation and immediately claimed that Mlinar had been attacked by Croats on account of his ethnicity and affiliation with the SDS. The articles in the Serbian press about the attack on Mlinar were replete with terms such as "centuries old threat", "Ustashas", and "butchers". The tenor of every one of these articles could best be described as bellicose and warmongering in nature. The titles of some of these articles were as follows: "Dialogue from an Ambush" (Novosti, May 21, 1990), "Ugly, Callous, Ustashe Act" (Politika, May 21, 1990), "Aggression with the Ustasha Signature" and "Attack on the Serbian People" (Politika, May 22, 1990), "Straight through the Heart" (Duga, June 8, 1990), "My Tragedy Is the Tragedy of the Serbian People" (Politika, June 17, 1990), etc.

The Serb extremists staged the "Mlinar case" in an attempt to aggravate the already tense situation and to portray the new Croatian government as anti-Serbian and fascist. But, the Serbian journalist Dragan Tanasić wrote an article entitled "The case of 'butchered' Mlinar", in which he quoted the testimony of one of the rebel Serb leaders, Jovan Rašković, and exposed that the attack on Mlinar had been staged. Mlinar personally admitted this to Raskovic after examining his wounds as a physician and concluding that they were not inflicted in the way the media claimed. ${ }^{39}$

Despite this, the SDS used the staged attack as a pretext to cut its ties with the Croatian Assembly, refuse to name a Serb candidate and boycott the constitutive session of the Croatian Parliament (May 30, 1990). The representative of the Orthodox Christian community, the Metropolitan Bishop of

\footnotetext{
39 According to Dragan Tanasić, “Zaboravljeni testament Jovana Raškovića” [The Forgotten Legacy of Jovan Rašković], Profil (2004), No. 47: 4-6, upon "his return from America, Jovan Rašković immediately visited his young protégé and friend (Miroslav Mlinar) and asked him to describe, down to the tiniest detail, what had happened to him (...). Mlinar pretty much repeated the story from the newspapers. (...) Rašković then carefully examined his neck and hand. There were superficial wounds there, barely visible, obviously tenderly and expertly inflicted?! Rašković then looked Mlinar in the eye and asked in dismay: "Why, in God's name, did you bring shame on yourself, on the Serb Democratic Party and on me too?" Mlinar proceeded to repeat once again the narrative from the press but Rašković sharply interrupted him: "Don't you try to pull wool over my eyes, son. I'm a doctor. There's no hand in the world that can hold a razor steady. Especially if two men are wrestling over it. It is impossible not to cut deep, it is impossible not to damage blood vessels in the neck. It is even more impossible to snatch the razor away from the attacker without him butchering your hand." Then, Mlinar meekly said: “I was forced to do it!". Miroslav Mlinar participated in Serb aggression against the Republic of Croatia as a member of Serb forces. The County Court in Zadar found him guilty of participating in a war crime committed on November 18, 1991, against Croatian civilians in Škabrnja and another war crime committed on November 11, 1995. He was sentenced to 20 years in prison (Case number: K-25/94).
} 
Zagreb and Ljubljana Jovan Pavlović, also boycotted the session even though he was invited. The representatives of the other religious communities in Croatia were present at the session. ${ }^{40}$ With these moves the leadership of the rebel Serbs in Croatia sent a clear and unambiguous message about its view regarding cooperation with the Croatian leadership and Croatian political parties.

The "Mlinar case" was often mentioned in speeches given by SDS officials and Serb representatives in Croatia as "indisputable" proof that the policies of President Tuđman and the Croatian government were fascist and that, therefore, the Serbs needed to arm themselves and fight back. For example, Branko Marijanović, vice-president of the SDS, said, during his speech at the founding session of the Local SDS board in Smokvić on June 16 1990: "You all very well know that we froze our relations with the Croatian Parliament and with all Croat centrist parties, including Račan's SKH-SDP."

Bogoljub Popović, a JNA colonel and a member of the SDS, also mentioned the attack on Mlinar in his speech at the same gathering He said that "the wounds of Miroslav Mlinar, butchered half to death, have not healed yet" and stated: "We will connect the Serbs from the Adriatic to the Drina river, from Subotica to Kosovo (...) The Serb nation is in the process of unification and there is no earthly power that can stop the rejuvenation and the renaissance of the Serb people." ${ }^{31}$

One week later (June 23, 1990) the colonel said something similar in his speech at the founding of the Local SDS board in Kula Atlagić near Benkovac. This time he mentioned Franjo Tuđman: "The SDS does not recognize republic boundaries, the SDS does not recognize the continental boundaries and therefore it is no wonder that our mission is greeted with such enthusiasm across the Drina and across the Danube. The day when we'll connect our lands from the sea to the Drina is close. There is nothing that can prevent us from uniting the Serb people. Tuđman or Račan or whomever can't foil our plan. So, you see, there is no chance in hell that we'll have a repeat of 1941. We shall not be victims anymore, and we will have our lands across the Drina. We will not let ourselves be butchered, as the poet Jovan Radulović says. If it turns out that this confederacy thing comes into being, well, you all know what our president said about that. We will be up in arms. Autonomy is our weapon. We also believe in the JNA. The JNA defends our interests and the interests of Yugoslavia. Long live the JNA!"42

\footnotetext{
40 Ante Nazor, Počeci suvremene hrvatske države [The Origins of Modern Croatian State] (Zagreb, 2007), 30.

41 HMDCDR - Footage collection; Republika Hrvatska i Domovinski rat 1990-1995, knjiga 2, pp. 28-29.
}

42 Republika Hrvatska i Domovinski rat 1990-1995, knjiga 2, p. 30. 
The mentioned speeches of the SDS officials given in June, 1990, in which they emphasized that the SDS did not recognize the republic boundaries and announced that the Serbs would be connected "from the Adriatic to the Drina river, from Subotica (Vojvodina) to Kosovo", are the showcase of the way of thinking of part of the Serbs in Croatia and what the aims of the SDS's policies were. Besides declaring the unification of all Serbs these speeches manifested hatred not only towards President Tuđman but also towards the leader of the second strongest political party in Croatia - Ivica Račan, the President of the Croatian Communist Party - Party of Democratic Changes (today Social Democratic Party). It is important to mention that President Tuđman fought for the Communist side in WWII. He rose to the rank of general in Yugoslav People's Army and fought against the NDH and the Ustashas. In the light of that fact, the accusations leveled by the Serbs against Tuđman that he was bent on resurrecting the NDH can only be described as absurd. Equally absurd were their specious arguments according to which Ivica Račan - the leader of the political party that succeeded the Croatian Communist Party - was engaged in denigrating Serbs and colluding with Tuđman in continuing the $\mathrm{NDH}$ regime's prosecution and persecution of Serbs.

In the same context of alleged "cooperation against Serbs", Tuđman and Račan were referred to in a lawsuit filed on October 26, 1990, in the Russel Tribunal (Ljubljana, Oslo, New York) by the Yugoslav Independent Democratic Party against the Croatian government for "ongoing genocidal practice and preparations for a genocide of gigantic proportions against the Serbs in Croatia". The accusations laid out by the Yugoslav Independent Democratic Party are not worthy of comment. The statements in the text of the lawsuit are ludicrous, more than anything else. One of those statements reads as follows: "Ivica Račan, in complete collaboration with Mister Tuđman, embraced the anti-Serb policies and is getting paid handsomely by the Croatian government for the effort". President Tuđman is depicted as a revisionist who "scandalously downplays the number of Serb victims in the Jasenovac camp - from half a million to $40,000^{\prime \prime 3}$ and characterized, without providing a shred of

43 According to Serb propaganda, between 500,000 and 1,000,000 people were killed in the Jasenovac camp. The number is a preposterous exaggeration. A list of 72,193 victims in the Jasenovac and Stara Gradiška camps is included in the book Poimenični popis žrtava koncentracijskog logora Jasenovac 1941.-1945 (List of names of the victims in the Jasenovac concentration camp 1941-1945) (Tea Benčić Rimay, ed., 1. izdanje, Jasenovac: Spomen - područje Jasenovac, 2007). In the introduction (page 8) to the book it is explained that the list is based on Poimenični popis žrtava Drugog svjetskog rata u Jugoslaviji (List of names of victims in WWII in Yugoslavia). That list is the most comprehensive list of people killed during WWII in Yugoslavia (it contains 597,323 names, irrespective of the locality of death and identity of the perpetrators). It was compiled by the Federal Institute for Statistics of Yugoslavia in 1964 on the basis of Imenični popis Zemaljske komisije za utvrdivanje zločina okupatora i njihovih 
evidence, as one of "the Croatian party leaders and state officials in Croatia who glorify the NDH". At the same time, the authors of the lawsuit parrot one of the favorite Communist propaganda pieces of gibberish which was aggressively promulgated during the era of Communist Yugoslavia and according to which "900,000 Serbs, out of 2,350,000 who lived in the NDH/today Croatia, Bosnia and Herzegovina and Sirmium were put to death". ${ }^{44}$ The number is a ludicrous exaggeration of the actual Serb victims in WWII in the NDH. ${ }^{45}$

The Serb occupation authorities passed a Declaration on September 11, 1991, having occupied the region of Baranja. The text of the Declaration was just a rehash of everything the Serb propaganda was dishing out at the time. President Tuđman was accused of "plotting genocide with his associates against everything that is not Croatian and loyal to the Croatian leadership". ${ }^{46}$ On February 26, 1992, at a session of the RSK Assembly in Borovo Selo, the president of the Assembly, Mile Paspalj, thought it convenient to add

pomagača iz 1946. (List composed by the Commission for investigating crimes of the occupiers and their collaborators, 1946), and data gathered from the SUBNOR-a (Association of WWII Partisan Veterans). According to later research conducted by Vladimir Žerjavić, the total number of victims during WWII is around 1,027,000. Bogoljub Kočović, a Serbian scholar, also researched the issue. According to his findings, 1,014,000 people were killed in Yugoslavia during WWII. The mentioned list from 1964 and the subsequent studies confirm that the claim that 500,000 or even a million people allegedly killed in the Jasenovac camp is a product of shameless Serb propaganda and manipulation. According to the 1964 list, 59,000 people were killed in the Jasenovac and Stara Gradiška camps. According to the current exhibition of the Jasenovac museum 83,145 people were killed there during WWII. That number corresponds with Žerjavić's estimate regarding the Jasenovac camp. However, due to numerous mistakes and flaws in the current list, as well as in the 2007 list, it is possible that the real number of victims is significantly closer to the number given by president Tuđman which was in his own research. The mentioned lists need to be revised and serious scholarly effort needs to be brought to bear on the mentioned lists and studies for the purpose of ascertaining the real number of victims. For more information on the issue of the number of Jasenovac victims: Vladimir Geiger, "Pitanje broja žrtava logora Jasenovac u hrvatskoj i srpskoj historiografiji, publicistici i javnosti nakon raspada SFR Jugoslavije - činjenice, kontroverze i manipulacije” ["The Issue of the Number of Victims in the Jasenovac Camp in Croatian and Serbian Historiography, Publishing and Press after the Break-Up of the SFRY - Facts, Controversies and Manipulations"], Časopis za suvremenu povijest 52 (2020), No. 2: 517-587.

44 Republika Hrvatska i Domovinski rat 1990-1995, knjiga 2, pp. 89-103.

45 According to Vladimir Žerjavić's research, in which he used the official 1964 list, 322,000 Serbs were killed in the NDH from 1941-1945; about 82,000 were soldiers, 93,000 people were killed by the Ustasha authorities in prisons, camps and executions, around 124,000 people were killed in villages and towns and around 23,000 people were killed as collaborators of the Nazis and fascists. Vladimir Žerjavić, Opsesije i megalomanije oko Jasenovca i Bleiburga (Zagreb: Globus, 1992), pp. 35 and 70. It is possible that cited numbers are exaggerated, especially in relation to the prisons and camps. More research into the matter is needed.

46 The Republic of Croatia, the Office of the President, 247/01. 
to the chorus of Serb propaganda and concluded that "Tuđman's authority is set up so as to function as a criminal machinery geared towards destroying everything that is not Croatian or greater Croatian" ${ }^{47}$ The authors of informative circulars of the Command of VII Corps SVK in Knin perceived the fact that "Tuđman managed to hold on to power through wartime circumstances in the elections" (parliamentary and presidential elections held on August 2, 1992) as "a testimony to the complete totalitarization of the national Croatian state and its subordination to the ideology of Fascism". ${ }^{48}$

Of course, the data contained in the mentioned sources are worthless in the context of any given scholarly analysis. However, they do show the level of depravity of the practitioners of anti-Croatian propaganda and expose their intention to fool the international public into believing that the modern state of Croatia was a successor polity to the NDH. More often than not, in the service of the mentioned objective, the authors used the words genocide, Ustashas, fascists with abandon. The Republic of Croatia, by the same token, was often referred to as the NDH and the Croatian government's policies were characterized as "Ustasha", "national-Fascist", "neo-Nazi-imperial", and similar. ${ }^{49}$ The implication was that Tuđman was all of the above. In addition, he was often referred to as Poglavnik (the official title of Ante Pavelić, the head of the $\mathrm{NDH}) .{ }^{50}$ These preposterous and easily refuted constructs actually reveal the intellectual level the leadership of the rebel Serbs operated at. They also expose the depths of moral depravity the Serb leaders sank into. The real tragedy of the situation was that President Tuđman and Croatian leadership were forced to negotiate with these people during the Croatian War of Independence.

In relation to everything described above it should not surprise us that Serb legal "experts" proclaimed Tuđman, together with Tomislav Merčep and Gojko Šušak, responsible for the Croat-Serb conflict and guilty of "war crimes and genocide" against "Krajina Serbs" during the first half of the 1990s. In a

\footnotetext{
47 Republika Hrvatska i Domovinski rat 1990-1995, knjiga 4: Dokumenti institucija pobunjenih Srba u Republici Hrvatskoj, siječanj-lipanj 1992 [The Republic of Croatia and the Homeland War 1990-1995, Vol. 4: Documents of the Institutions of Rebel Serbs in the Republic of Croatia, January-June 1992], Mate Rupić, ed. (Zagreb-Slavonski Brod, 2008), p. 141.

48 Republika Hrvatska i Domovinski rat 1990-1995, knjiga 7: Dokumenti vojne provenijencije "Republike Srpske Krajine", siječanj-lipanj 1993 [The Republic of Croatia and the Homeland War 1990-1995, Vol. 7: Documents of military provenance of the "Republic of Serbian Krajina”, January-June 1993], Mate Rupić, ed. (Zagreb, 2009), p. 172.

49 Republika Hrvatska i Domovinski rat 1990-1995, knjiga 13: Dokumenti vojne provenijencije "Republike Srpske Krajine", srpanj-prosinac 1994 [The Republic of Croatia and the Homeland War 1990-1995, Vol. 13: Documents of military provenance of the Republic of Serbian Krajina, July-December 1993], Mate Rupić, ed., (Zagreb, 2013), pp. 69, 122, 170, 236 and 452.

$50 \quad$ Ibidem, 452.
} 
memo of the RSK State Commission for War Crimes and Crime of Genocide signed by the president of the Commission Mile Dakić and sent to the Ministry of Law and Justice of RSK on September 30, 1994, it was, amongst other things, stated:

"Doctor Franjo Tuđman, the President of the Republic of Croatia, is responsible, as commander in chief of the Croatian Army and police force for repeated crimes against Serb civilians in the war 1991-1994. He is the creator of the neo-Ustasha movement and the most responsible person for the Croat-Serb war. He created his political image exclusively on fanning the flames of hatred between the Croats and Serbs. Just like Doctor Ante Pavelić, a war criminal, Franjo Tuđman tried to deny the Serbs their centuries long status of a people and reduce them to the position of a national minority, which caused the war." 51

The quoted passage, in which the Croatian president is falsely accused for something that did not happen at all, and in which the real cause of the war is obscured, shows the prevailing attitude of the Serbian press and the Serbian public in general towards Tuđman during the Croatian War of Independence.

It has to be pointed out that it is a fact that "the organizations tasked with fact gathering, like the UN, US Ministry of Foreign Affairs, CIA, Helsinki Watch and others, unanimously concluded that $90 \%$ of the war crimes committed during the wars in the former Yugoslavia were perpetrated by the Serb side. These organizations also concluded that all acts of genocide as defined by the UN, committed during the wars were perpetrated by the Serb side. The UN definition of genocide reads as follows:

"Any of the following acts committed with intent to destroy, in whole or in part, a national, ethnical, racial or religious group, as such: killing members of the group; causing serious bodily or mental harm to members of the group; deliberately inflicting on the group conditions of life, calculated to bring about its physical destruction in whole or in part; imposing measures intended to prevent births within the group; [and] forcibly transferring children of the group to another group. (Article 2 CPPCG)" 52

\footnotetext{
51 Republika Hrvatska i Domovinski rat 1990-1995, knjiga 14: Dokumenti institucija pobunjenih Srba u Republici Hrvatskoj, srpanj-prosinac 1994 [The Republic of Croatia and the Croatian War of Independence 1990-1995, Vol. 14: Documents of the Institutions of Rebel Serbs in the Republic of Croatia, July-December 1993], Mate Rupić, ed., (Zagreb-Slavonski Brod, 2013), p. 181.

52 Žunec, Goli život, p. 111 (fn. 181).
} 


\section{Conclusion}

The initiatives for creating the conditions for cooperation between the Serbs and Croats in Croatia proposed by the Croatian government and the constitutional and legal decisions about protecting the rights of national minorities that the Croatian leadership reached during the mandate of Franjo Tuđman represented a solid basis for coexistence of all Croatian citizens. The Serb leadership in the temporarily occupied areas of the Republic of Croatia rejected or ignored the mentioned initiatives and laws and claimed that President Tuđman was implementing criminal policies towards the Serbs and that "he is the creator of the neo-Ustasha movement and the most responsible person for the Croat-Serb war. He created his political image exclusively on fanning the flames of hatred between the Croats and Serbs". These accusations, as well as the attempt to portray the democratically elected Croatian government led by Franjo Tuđman as "national-Fascist" and "Ustasha" and characterize the Republic of Croatia as a successor polity to the NDH, are not only factually incorrect but completely absurd, especially in light of the fact that President Tuđman, during WWII, was a member of the armed force that fought against the Nazi and Fascist forces in Croatia and against the Ustasha regime in the $\mathrm{NDH}$.

The representatives of the rebel Serbs in Croatia also accused Ivica Račan, the president of the then League of Communists of Croatia - the Party of Democratic Changes (today Social Democratic Party) of engaging in anti-Serb policies. That accusation, coupled with all the other ludicrous allegations, clearly shows that the anti-Croatian propaganda campaign launched by the Serbs had no basis whatsoever but was utilized solely for the purpose of homogenizing the Serbs and creating a greater Serbian state.

\section{Sources and Literature}

Barić, Nikica. "Prvi hrvatski predsjednik dr. Franjo Tuđman o jugoslavenskom predsjedniku Josipu Brozu Titu", in: Dr. Franjo Tudman u okviru hrvatske historiografije. Zagreb, 2011.

Degan, Vladimir Đuro. Hrvatska država u međunarodnoj Zajednici - Razvitak njezine medunarodno pravne osobnosti tijekom povijesti. Zagreb: Nakladni zavod Globus, 2002.

Degoricija, Slavko. Nije bilo uzalud. Zagreb: Nova Stvarnost, 2009.

Geiger, Vladimir. "Pitanje broja žrtava logora Jasenovac u hrvatskoj i srpskoj historiografiji, publicistici i javnosti nakon raspada SFR Jugoslavije - či- 
njenice, kontroverze i manipulacije”, Časopis za suvremenu povijest 52 (2020), No. 2: 517-587.

"Dokumentacija Ustavnog suda Republike Hrvatske o Domovinskom ratu", Hrvatsko slovo, No. 400, December 20, 2002, Appendix.

Kačić, Hrvoje. U službi domovine. Zagreb, 2006.

Kadijević, Veljko. Moje viđenje raspada. Belgrade, 1993.

Marijan, Davor. Slom Titove armije - JNA i raspad Jugoslavije 1987-1992. Zagreb, 2008.

Nazor, Ante. Počeci suvremene hrvatske države. Zagreb, 2007.

Narodne novine, issue 56, December 22, 1990.

Narodne novine, issue 53, October 8, 1991.

Narodne novine, issue 65/91.

Narodne novine, issue 27/92

Narodne novine, br. 34/92

Narodne novine, issue 60/92.

Poimenični popis žrtava koncentracijskog logora Jasenovac 1941.-1945., Tea Benčić Rimay, ed., First edition. Jasenovac: Spomen - područje Jasenovac, 2007.

Pupovac, Milorad. "Raspad Jugoslavije i Srbi u Hrvatskoj”, Ljetopis Srpskog kulturnog društva "Prosvjeta", II (1997): 256-264.

Radelić, Zdenko; Marijan, Davor; Barić, Nikica; Bing, Albert and Živić, Dražen. Stvaranje hrvatske države i Domovinski rat. Zagreb: Školska knjiga, Hrvatski institut za povijest, 2006.

Republika Hrvatska, Ured predsjednika RH, 247/01

Republika Hrvatska i Domovinski rat 1990-1995, Dokumenti, knjiga 1, Oružana pobuna Srba u Hrvatskoj i agresija Oružanih snaga SFRJ i srpskih paravojnih postrojbi na Republiku Hrvatsku, 1990-1991, Mate Rupić, ed. Zagreb: Hrvatski memorijalno-dokumentacijski centar Domovinskog rata, 2007.

Republika Hrvatska i Domovinski rat 1990-1995, dokumenti, knjiga 2, Dokumenti institucija pobunjenih Srba u Republici Hrvatskoj, 1990-1995, Mate Rupić ed. Zagreb: Hrvatski memorijalno-dokumentacijski centar Domovinskog rata, 2007.

Republika Hrvatska i Domovinski rat 1990-1995, knjiga 4: Dokumenti institucija pobunjenih Srba u Republici Hrvatskoj, siječanj-lipanj 1992, Mate Rupić, ed. Zagreb-Slavonski Brod, 2008. 
Republika Hrvatska i Domovinski rat 1990-1995, knjiga 7: Dokumenti vojne provenijencije "Republike Srpske Krajine", siječanj-lipanj 1993, Mate Rupić, ed. Zagreb, 2009.

Republika Hrvatska i Domovinski rat 1990-1995, knjiga 13: Dokumenti vojne provenijencije "Republike Srpske Krajine", srpanj-prosinac 1994, Mate Rupić, ed. Zagreb, 2013.

Republika Hrvatska i Domovinski rat 1990-1995, knjiga 14: Dokumenti institucija pobunjenih Srba u Republici Hrvatskoj, srpanj-prosinac 1994, Mate Rupić, ed. Zagreb-Slavonski Brod, 2013.

Sadkovich, James John. Tudman, prva politička biografija. Zagreb, 2010.

Tanasić, Dragan. “Zaboravljeni testament Jovana Raškovića”, Profil (2004), No. 47: 1-9.

Tus, Anton. "Rat u Sloveniji i Hrvatskoj do Sarajevskog primirja”, in. Rat u Hrvatskoj i Bosni i Hercegovini 1991.-1995. Zagreb-Sarajevo: Naklada Jesenski i Turk - Dani, 1999.

"Ustav Republike Hrvatske", Narodne novine, issue 56, December 22, 1990.

Ustav SFR Jugoslavije - Ustav SR Hrvatske, ekspoze Jakova Blaževića. Zagreb, 1974.

Zbirka zakona, uredaba i naredaba Narodne Republike Hrvatske, broj 5, Ustav Narodne Republike Hrvatske. Zagreb, 1947.

Žerjavić, Vladimir. Opsesije i megalomanije oko Jasenovca i Bleiburga. Zagreb: Globus, 1992.

Žunec, Ozren. Goli život: Socijetalne dimenzije pobune Srba u Hrvatskoj, I. Zagreb: Demetra, 2007. 